\title{
Ependymal Tumor of Brain and Spinal Cord
}

National Cancer Institute

\section{Source}

National Cancer Institute. Ependymal Tumor of Brain and Spinal Cord. NCI Thesaurus.

Code C131610.

An ependymal tumor affecting the brain and spinal cord. 